\section{'Goldnine' Peach}

\author{
John R. Clark ${ }^{1}$, James N. Moore ${ }^{2}$, and Roy C. Rom ${ }^{3}$ \\ Department of Horticulture, University of Arkansas, Fayetteville, AR 72701
}

Additional index words. Prunus persica, fruit breeding, bacterial spot, Xanthomonas campestris pv. pruni, processing peaches

'Goldnine' is the third non-melting flesh, clingstone peach [Prunus persica (L.) Batsch] released from the Univ. of Arkansas peach breeding program. Previous releases were 'Allgold' and 'Goldilocks' (Moore et al., 1984).

'Goldnine' is an early, clingstone processing peach that has reliable production, excellent flower bud hardiness, later than average bloom date, above average resistance to bacterial spot [caused by Xanthomonas campestris pv. pruni (Smith) Dye], and good processing attributes. It is being released as an early to mid-season processing peach for cultivation primarily in northern regions of the United States with cooler summers than the deep South and for potential use as a fresh-market cultivar in areas desiring a non-melting flesh, clingstone peach for the fresh market (Mexico).

'Goldnine', which was officially named in 2000 , has been marketed by commercial nurseries in the United States and Mexico as 'Arkansas 9', 'Ark. 9', or 'A-9'. In a census of peach cultivars planted in Michigan in 1997, 'A-9' was planted on 99 ha (Bill Shane, personal communication), with increased plantings anticipated, and 'Goldnine' was used for processing. In 1999, 'A-9' was one of the more commonly planted peaches in the highlands near Casas Grandes, Chihuahua, Mexico, with 30 ha in production for the fresh market (Jaime Martinez, personal communication).

\section{Origin}

'Goldnine' resulted from a cross of NJ $554367 \times$ G17-5E made in 1963 by Catherine Bailey and L.F. Hough of Rutgers Univ., New Brunswick, N.J.(Fig. 1). The original seedling trees of this cross were planted at the Univ. of Arkansas Fruit Substation, Clarksville, in 1964, and the original tree was selected in 1966 by J.N.M and R.C.R. and tested thereafter as 'Ark. 9'.

The primary testing of 'Goldnine' was at

Received for publication 7 Apr. 2000. Accepted for publication 5 Oct. 2000. Published with approval of the Director, Arkansas Agricultural Experiment Station, manuscript no. 00028. We thank Curt Rom, Bryan Blackburn, Effie Gilmore, David Gilmore, Patrick Byers, Robert Bourne, Jack Young, Stanley Brown, William Sistrunk, and Alfredo Gonzalez for assistance in data collection during the evaluation of 'Goldnine'. The cost of publishing this paper was defrayed in part by the payment of page charges. Under postal regulations, this paper therefore must be hereby marked advertisement solely to indicate this fact.

1Professor. E-mail address: jrclark@uark.edu ${ }^{2}$ Distinguished Professor Emeritus.

${ }^{3}$ University Professor Emeritus. the Fruit Substation, Clarksville, Ark. [westcentral Arkansas, lat. $35^{\circ} 31^{\prime} 58^{\prime} \mathrm{N}$ and long. $93^{\circ} 24^{\prime} 412^{\prime} \mathrm{W}$; U.S. Dept. of Agriculture (USDA) hardiness zone 7a; soil type Linker fine sandy loam (Typic Hapludults)], with testing also at the Southwest Arkansas Research and Extension Center, Hope [southwest Arkansas, lat. $33^{\circ} 42^{\prime} 30^{\prime}$ and long.

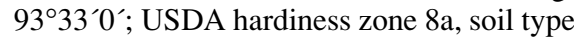
Bowie fine sandy loam (Fragic Palendults)]. Additional evaluation plantings were established in southwest Michigan and Princeton, Ky. In all Arkansas testing, trees were trained to an open-center system and pruned annually, spaced $5.5 \mathrm{~m}$ between trees, fertilized annually with either complete or nitrogen fertilizers, irrigated as needed, and pests managed using a pest management program typical for commercial orchards of the area, including the applications of fungicides and insecticides. Fruit were thinned each year that a crop was present to a distance of $12 \mathrm{~cm}$ between fruit prior to pit hardening but after shuck split.

Trials consisting of two-tree observational plots were maintained at Clarksville and data were collected from these trees or the original tree from 1966 through 1999. Data are reported here only for a maximum of 9 years for any data point. Comparison cultivars also planted at this site included 'Babygold 5', but records do not indicate the meaning of "G" or "DIX."
'Babygold 7', 'Allgold', and 'Goldilocks'. Field observations included bloom date, bloom intensity, and fruit maturity date. Fruit maturity date was estimated for first commercial harvest. Fruit ratings were taken for size, shape, firmness, skin color, flesh color, finish, and flavor. Trees were rated for vigor, crop, health, and bacterial spot susceptibility. The rating scale for these variables was 1 to 10 with a rating of 10 most desirable, with the exception of vigor, in which a rating of 10 indicated excessive vigor. A rating of 7 to 8 would be most desirable for vigor in this rating scale. Additionally, a five-fruit sample was collected from 'Goldnine' for 9 years (1988, 1990-95, 1997-98) and average fruit weight, fruit size, color (using a model CR200 chroma meter, Minolta, Ramsey, N.J.), firmness (using a model FT327 fruit pressure tester with an 11mm-diameter probe; McCormick Fruit Tree Co., Yakima, Wash.), and soluble solids (using a bench refractometer) were determined. In some years all variables were not measured and this is noted in the text. A replicated trial at Hope was established in 1992 and data were collected for yield and fruit weight in 1995 and 1997 (crops were lost or damaged by spring frosts in 1994 and 1996). Four single-tree replications arranged in a randomized complete-block design were utilized in this planting and data were analyzed separately for each year. Data from the replicated trial at Hope were analyzed by analysis of variance and means separated by least significant difference (LSD) (SAS Institute, 1989).

Processing evaluations were conducted in 1988, 1994, and 1995 by the Dept. of Food Science, Univ. of Arkansas, from $\approx 20-\mathrm{kg}$ samples collected at Clarksville and delivered to Fayetteville. For all processing samples, fruit were peeled, pitted, and blanched in live

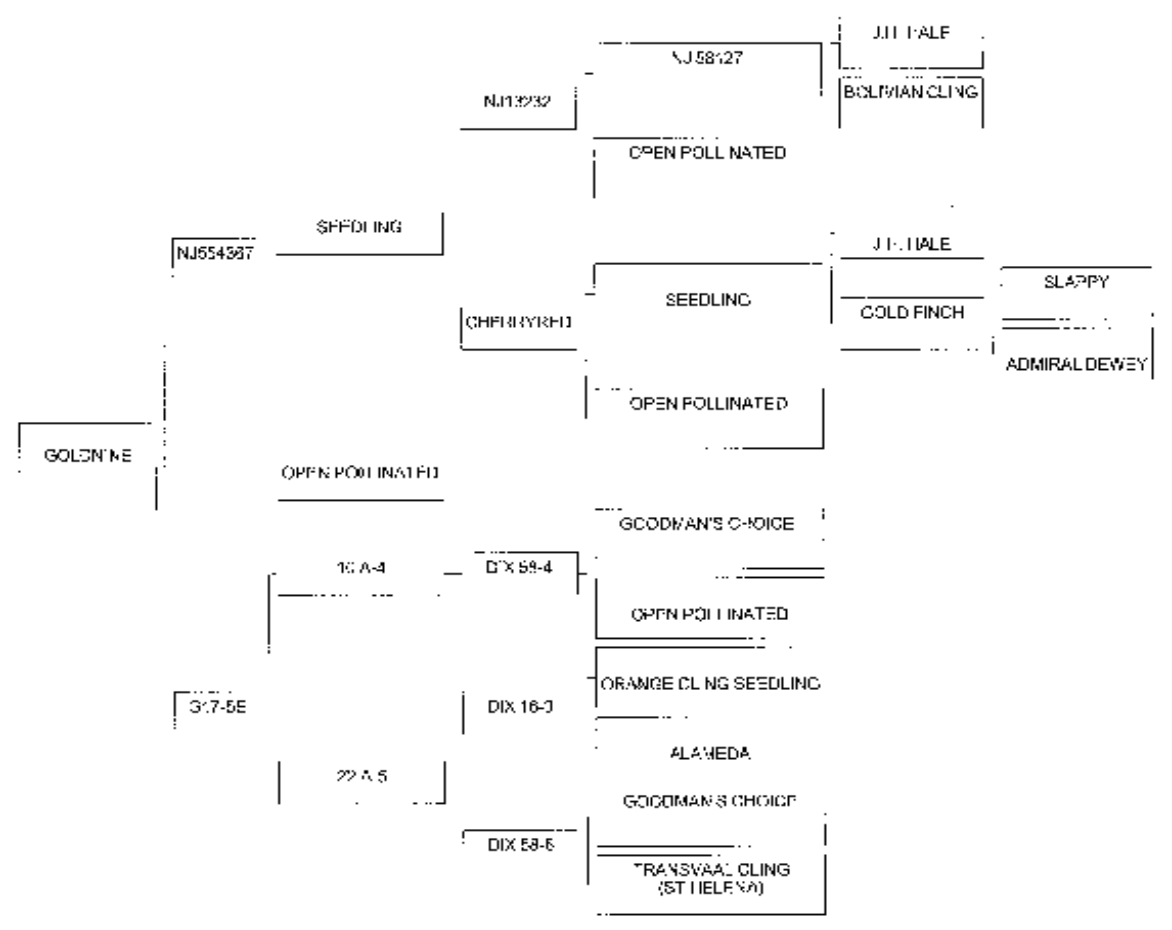

Fig. 1. Pedigree of 'Goldnine' peach. $\mathrm{NJ}=\mathrm{New}$ Jersey and G17-5E is a California-developed cling selection, 
steam for 5 min and then packed in a $0.5-\mathrm{L}$ glass jar, which was exhausted for $10 \mathrm{~min}$, sealed, and cooked for $25 \mathrm{~min}$ in boiling water. Soluble solids were measured with a bench refractometer from a blended, filtered sample. Titratable acidity and $\mathrm{pH}$ were measured on a $10 \mathrm{-g}$ blended sample diluted in $50 \mathrm{~mL}$ of deionized water, and titration utilized $0.1 \mathrm{~N}$ $\mathrm{NaOH}$ and was taken to a $\mathrm{pH}$ of 8.2. These measurements were obtained for both fresh fruit (represented as the fresh-slice data in Table 1), and processing samples (represented in the canned slices and canned puree data in Table 1). Processed sample color was determined by a Gardner Color Difference Meter (Colorguard System 1000 Colorimeter; Gardner/Neotec Instrument Division of Pacific Scientific Co., Silver Spring, Md.) that was standardized with a plaque $(\mathrm{L}=93.5, \mathrm{a}=$ 1.4 , and $b=3.2$ ). Sensory evaluations were also conducted on processed samples by a trained panel of 10 to 15 evaluators. These evaluations were done 3 to 4 months following processing of the fruit, and panelists rated the samples for color and flavor.

\section{Description and performance}

Average $10 \%$ bloom date at Clarksville for 'Goldnine' was 18 Mar., 1 d later than 'Goldilocks' and 'Babygold 5', and 3 d later than that for 'Allgold' and 'Babygold 7' (Table 2). Average full bloom date for 'Goldnine' was later than all comparison cultivars by 2 to $3 \mathrm{~d}$ (Table 2). Intensity of bloom ratings averaged over 9 years for 'Goldnine', a reflection of the amount of bloom, exceeded those for 'Allgold', 'Goldilocks', 'Babygold 5', and 'Babygold 7' (data not shown). Flowers of 'Goldnine' are showy and self-fertile. Leaf glands are reniform. Tree vigor was rated slightly lower than that for 'Allgold' and 'Goldilocks' (Table 2), although this difference was minimal and would not affect canopy management decisions. Crop load ratings conducted at fruit maturity were generally similar to the test cultivars (Table 3 ). Consistent cropping was achieved in all years of fruiting except when frosts near bloom eliminated the crop. Ratings for tree health for 'Goldnine' were between those for 'Allgold' and 'Goldilocks' (Table 3). 'Goldnine' was comparable with 'Allgold' in bacterial spot resistance, and less susceptible to this disease than were 'Goldilocks' and 'Babygold 5' (data not shown). In some years a limited number of bacterial spot lesions were seen on leaves of 'Goldnine' but defoliation was not a concern. Bacterial spot lesions were rarely seen on fruit and, when seen, were very minimal. No other disease problems have been seen on 'Goldnine', although a commercial fungicide program was used to control brown rot [caused by Monilinia fructicola (G. Wint.) Honey]. Peach scab (caused by Cladosporium carpophilum Thuem.) was observed on the fruit of 'Goldnine' 1 year at Hope, but was judged to be no more severe than on other cultivars in the planting.

Winter bud hardiness is very good for 'Goldnine' and is probably at least part of the

Table 1. Quality analyses of processing peach cultivars grown at the Univ. of Arkansas Fruit Substation, Clarksville.

\begin{tabular}{|c|c|c|c|c|}
\hline \multirow[b]{2}{*}{ Characteristic } & \multicolumn{4}{|c|}{ Cultivar } \\
\hline & Goldnine & Allgold & Goldilocks & Babygold 5 \\
\hline & \multicolumn{4}{|c|}{ Fresh slices $^{z}$} \\
\hline Soluble solids (\%) & 11.3 & 11.4 & 12.1 & 13.5 \\
\hline $\mathrm{pH}$ & 3.73 & 3.62 & 3.86 & 3.83 \\
\hline Titratable acidity $^{y}$ & 5.40 & 5.30 & 4.10 & 4.80 \\
\hline$C \mathrm{CM}^{\mathrm{x}}-\mathrm{L}$ & 56.3 & 65.7 & 60.3 & 62.4 \\
\hline CDM-a & 19.3 & 12.3 & 20.0 & 15.8 \\
\hline \multirow[t]{2}{*}{ CDM-b } & 30.6 & 35.1 & 34.1 & 34.7 \\
\hline & \multicolumn{4}{|c|}{ Canned slices $^{z}$} \\
\hline Soluble solids (\%) & 13.7 & 13.4 & 15.5 & 14.6 \\
\hline $\mathrm{pH}$ & 3.67 & 3.75 & 3.86 & 3.77 \\
\hline Titratable acidity & 4.70 & 4.00 & 3.60 & 4.50 \\
\hline CDM-L & 67.5 & 68.8 & 66.0 & 69.3 \\
\hline CDM-a & 9.8 & 10.9 & 13.5 & 10.0 \\
\hline \multirow[t]{2}{*}{ CDM-b } & 36.8 & 38.6 & 37.3 & 37.8 \\
\hline & \multicolumn{4}{|c|}{ Canned puree $^{w}$} \\
\hline Soluble solids (\%) & 13.6 & 15.0 & 14.4 & --- \\
\hline $\mathrm{pH}$ & 3.60 & 3.79 & 3.93 & --- \\
\hline Titratable acidity & 5.20 & 4.70 & 3.10 & --- \\
\hline CDM-L & 46.1 & 46.0 & 50.5 & --- \\
\hline CDM-a & 11.7 & 11.3 & 14.3 & --- \\
\hline CDM-b & 26.6 & 27.0 & 29.1 & --- \\
\hline
\end{tabular}

${ }^{\mathrm{z}}$ Means for 3 years: 1984, 1986, 1994.

${ }^{\mathrm{y}}$ Titratable acidity as malic acid in $\mathrm{g} \cdot \mathrm{L}^{-1}$.

${ }^{\mathrm{x}} \mathrm{CDM}=$ Color difference meter; the lower the $\mathrm{L}$ value, the darker the sample; the higher the a value, the redder the sample; the higher the $\mathrm{b}$ value, the more yellow the sample.

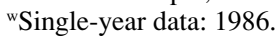

Table 2. Bloom and harvest dates and fruit characteristics of processing peach cultivars, Univ. of Arkansas Fruit Substation, Clarksville.

\begin{tabular}{|c|c|c|c|c|c|c|}
\hline \multirow[b]{2}{*}{ Cultivar } & \multicolumn{2}{|c|}{ Bloom date $^{z}$} & \multirow{2}{*}{$\begin{array}{c}\text { Harvest } \\
\text { date }^{y}\end{array}$} & \multirow{2}{*}{$\begin{array}{c}\text { Fruit } w^{t^{y}} \\
(\mathrm{~g})\end{array}$} & \multirow{2}{*}{$\begin{array}{c}\text { Fruit firmness }^{x} \\
(\mathrm{~kg})\end{array}$} & \multirow{2}{*}{$\begin{array}{c}\text { Soluble } \\
\text { solids }(\%)^{\mathrm{w}}\end{array}$} \\
\hline & $10 \%$ & full & & & & \\
\hline Goldnine & 18 Mar. & 26 Mar. & 11 July & 187 & 4.8 & 12.7 \\
\hline Allgold & 15 Mar. & 23 Mar. & 1 July & 204 & 3.3 & 12.1 \\
\hline Goldilocks & 17 Mar. & 24 Mar. & 18 July & 147 & 5.2 & 12.6 \\
\hline Babygold 5 & 17 Mar. & 24 Mar. & 21 July & 153 & 5.8 & 14.0 \\
\hline Babygold 7 & 15 Mar. & 23 Mar. & 30 July & 170 & 6.6 & 13.3 \\
\hline
\end{tabular}

${ }^{2}$ Means for 9 years: $1988,1990-95,1997-98$.

${ }^{\mathrm{y}}$ Means for 8 years: 1988, 1990-91, 1993-95, 1997-98.

${ }^{x}$ Means for 5 years: 1991, 1993-94, 1997-98; determined by a fruit pressure tester with an 11-mm-diameter on fresh, unpeeled samples.

${ }^{\text {w} M e a n s ~ f o r ~} 7$ years: 1990-91, 1993-95, 1997-98.

basis for its reliable cropping. Following -22 ${ }^{\circ} \mathrm{C}$ on 24 and 25 Dec. 1989 at Clarksville, percent flower bud survival for 'Goldnine' was $76 \%$ vs. $10 \%$ for 'Allgold' and $24 \%$ for 'Goldilocks'. In that same time period, data from Kentucky indicated that 'Goldnine' had $38 \%$ flower bud survival following exposure to $-26{ }^{\circ} \mathrm{C}$ vs. $2 \%$ survival for 'Redhaven' and $14 \%$ for 'Reliance' (Brown and Strang, 1990). Chilling requirement of 'Goldnine' has not been determined, but is probably near $750 \mathrm{~h}$ below $7^{\circ} \mathrm{C}$ based on observations of budbreak and bloom in comparative plantings with test cultivars of known chill requirement. In Chihuahua, Mexico, in 1999, 'Goldnine' fruited well with an estimated chilling of $500 \mathrm{~h}$ below $7{ }^{\circ} \mathrm{C}$. Budbreak of 'Babygold 5' and 'Babygold $7^{\prime}$ was reduced because of lack of adequate chilling (Jaime Martinez, personal communication).

Fruit of 'Goldnine' mature on average $10 \mathrm{~d}$ after 'Allgold', 7 d before 'Goldilocks', and 10 and $19 \mathrm{~d}$ before 'Babygold 5' and 'Babygold 7', respectively (Table 2). Yield data, collected at Hope for 1995 and 1997, indicated that 'Goldnine' had significantly higher yields than did 'Babygold 5' and 'Babygold 7' in 1997 and statistically similar yields in 1995 (Table 4). Fruit size ratings were similar to those for 'Goldilocks' and 'Babygold 5', but less than those for 'Allgold' and 'Babygold 7' (Table 2). Average fruit weight for 'Goldnine' over 8 years was $187 \mathrm{~g}$ and exceeded that of all comparison cultivars except 'Allgold' at Clarksville (Table 2). Fruit weight at Hope for 'Goldnine' was less than for 'Babygold 5' and 'Babygold 7', although crop loads for 'Goldnine' were heavier than for either of these comparison cultivars (Table 3 ). 'Goldnine' fruit averaged $6.1 \mathrm{~cm}$ in length and $7.1 \mathrm{~cm}$ in diameter in measurements taken over 9 years. Fruit shape, skin color, and finish ratings were generally similar among 'Goldnine' and the other cultivars evaluated (Table 3 ). The skin usually had $\approx 40 \%$ blush with some red striping when grown in Arkansas. Skin ground color (background color) had 7-year average values of 71.7 for $\mathrm{L}$ (the lower the $\mathrm{L}$ value, the darker the sample), 11.1 for a (the higher the a value, the redder the sample), 
Table 3. Subjective evaluations (based on a $1-10$ scale, with a rating of $<6$ considered unacceptable) of fruit and tree characteristics for processing peach cultivars. Data are means of 7 (1991-95, 1997-98) years and ratings are from the Univ. of Arkansas Fruit Substation, Clarksville.

\begin{tabular}{|c|c|c|c|c|c|}
\hline \multirow[b]{2}{*}{ Characteristic } & \multicolumn{5}{|c|}{ Cultivar } \\
\hline & Goldnine & Allgold & Goldilocks & Babygold 5 & Babygold 7 \\
\hline & & & Fruit & & \\
\hline Size $^{z}$ & 7.8 & 9.0 & 7.7 & 7.7 & 8.8 \\
\hline Shape ${ }^{\mathrm{y}}$ & 7.7 & 7.6 & 7.7 & 7.6 & 6.4 \\
\hline Firmness $^{\mathrm{x}}$ & 8.7 & 7.8 & 8.1 & 7.7 & 8.6 \\
\hline Skin $^{\mathrm{w}}$ & 7.5 & 8.1 & 8.0 & 7.3 & 7.6 \\
\hline Flesh $^{v}$ & 6.2 & 7.6 & 7.1 & 6.4 & 6.4 \\
\hline Finish $^{\mathrm{u}}$ & 7.7 & 8.0 & 7.7 & 6.7 & 7.4 \\
\hline \multirow[t]{2}{*}{ Flavor $^{t}$} & 7.5 & 7.4 & 7.6 & 7.3 & 6.8 \\
\hline & & & Tree & & \\
\hline Vigors $^{\mathrm{s}}$ & 7.8 & 8.3 & 8.1 & --- & --- \\
\hline Crop $^{r}$ & 8.7 & 8.6 & 8.3 & --- & --- \\
\hline Health $^{\mathrm{q}}$ & 8.2 & 9.0 & 7.4 & --- & --- \\
\hline
\end{tabular}

${ }^{\mathrm{z}} 10=$ very large fruit.

${ }^{y} 10=$ round or mostly round or uniform and free of bulging suture and blossom-end tip.

${ }^{x}$ Based on hand pressure applied to whole, unpeeled fruit with $10=$ very firm fruit.

${ }^{\text {w}}$ Preferred is a light, bright red-over-orange ground color with $10=$ full expression of these colors.

v'Preferred is uniform orange color with no trace of red pigment with $10=$ no red in flesh and uniform orange color.

"Preferred is bright finish free of any blemish or skin cracks or inconsistencies with $10=$ free of all surface blemishes or skin cracks.

'Ratings based on fresh samples; higher values indicate good sweetness and expression of peach flavor with little astringency or other undesirable flavor components.

${ }^{\text {s}}$ Ratings based on good shoot growth, but not overly vegetative; optimum is a rating of 7 to 8 with a rating of 10 considered excessive.

${ }^{\mathrm{r}} 10=$ full crop; $9=90 \%$ crop, etc.

${ }^{\mathrm{q}} 10=$ no disease or health concerns. The most important disease involved in this rating is bacterial spot, and a higher rating indicates a lower occurrence of this disease. Non-disease factors could involve poor health due to mineral deficiencies or insect damage.

and 59.9 for $b$ (the higher the $b$ value, the more yellow the sample), while skin over color values were 40.1 for $\mathrm{L}, 36.7$ for a, and 24.2 for b. Fruit firmness for 'Goldnine' was higher than for 'Allgold' in ratings and objective testing (Tables 2 and 3). Flesh color ratings were less desirable for 'Goldnine' than for 'Allgold' or 'Goldilocks', but near those for 'Babygold 5' and 'Babygold 7'. This reduced rating is due to the commonly seen red color in the flesh for 'Goldnine' in Arkansas. This red color was usually found not only around the pit of the fruit but also in the flesh, and the intensity of the red varied with year. 'Goldnine' was judged to have excess red in the flesh in some years in Arkansas trials and was not released prior to this time because of this limitation. However, less red pigment in the flesh was observed in cooler environments such as those found in southwest Michigan (Todd DeKryger, Gerber Products Co., personal communication). Flavor ratings were good for 'Goldnine', generally comparable to those of the other Arkansas cultivars and 'Babygold 5' but higher than for 'Babygold 7' (Table 3). Soluble solids content of orchard samples was near that of the other Arkansas cultivars but was exceeded slightly by
Table 4. Yield and fruit weight in 1995 and 1997 of processing peach cultivars grown at the Southwest Research and Extension Center, Hope, Ark.

\begin{tabular}{lcc}
\hline Cultivar & $\begin{array}{c}\text { Yield } \\
(\mathrm{kg} / \text { tree })\end{array}$ & $\begin{array}{c}\text { Avg fruit wt } \\
(\mathrm{g})\end{array}$ \\
\hline Goldnine & 1995 & \\
Babygold 5 & $54.5 \mathrm{a}^{\mathrm{y}}$ & $176 \mathrm{~b}$ \\
Babygold 7 & $50.8 \mathrm{a}$ & $189 \mathrm{ab}$ \\
& $43.3 \mathrm{a}$ & $208 \mathrm{a}$ \\
Goldnine & 1997 & \\
Babygold 5 & $107.7 \mathrm{a}$ & $149 \mathrm{~b}$ \\
Babygold 7 & $51.1 \mathrm{~b}$ & $247 \mathrm{a}$ \\
\hline
\end{tabular}

zPlanting established in 1992.

${ }^{y}$ Mean separation within columns and years by LSD $(P \leq 0.05)$.

being measured by the color difference meter. 'Goldnine' was more similar to 'Babygold 5' and 'Goldilocks' in fresh-slice a value, which was expected, since some red often occurs in the flesh of these two cultivars. Interestingly, the higher a value for 'Goldnine' was not observed in the canned slices or canned puree (Table 1). This may indicate that the red pigment in the flesh does not contribute to red color in the processed product. In sensory evaluations on pureed samples, averaged over 4 years, flavor of 'Goldnine' rated near that of 'Goldilocks' and 'Allgold', and higher than that of 'Babygold 5' (data not shown). Sensory values for color desirability were higher for 'Goldnine' than for 'Goldilocks' and 'Babygold 5' (data not shown).

The outstanding characteristics of 'Goldnine' are its reliable production, excellent flower bud hardiness, later than average bloom date, above average bacterial spot resistance, and good processing attributes. 'Goldnine' is recommended for trial where other eastern, North American-developed processing clingstone peaches are grown.

\section{Availability}

'Goldnine' is available from commercial nurseries under this name or as 'Arkansas 9', 'A-9', or 'Ark. 9'. A limited amount of budwood is available for research and evaluation purposes; requests can be sent to J.R.C., 316Plant Science, Dept. of Horticulture, Univ. of Arkansas, Fayetteville, AR 72701.

\section{Literature Cited}

values than other cultivars. Since red pigment in the flesh can lead to browning in a processed product (and presumably to a darker value), the lack of a lower $L$ value in processed samples is a positive finding. For the freshslice a values, 'Goldnine' was higher than 'Allgold' (in which no red is observed in the flesh), which indicates that the red is probably
Brown, G. and J. Strang. 1990. Fruit crop winter injury. Kentucky Fruit Facts 90-2:1-2.

Moore, J.N., R.C. Rom, S.A. Brown, and W.A Sistrunk. 1984. 'Allgold' and 'Goldilocks' peaches. HortScience 19:891-892.

SAS Institute. 1989. SAS/STAT user's guide, version 6, vol. 2. SAS Inst., Cary, N.C. 